Katarzyna Rychlicka-Maraszek

IPSiR

University of Warsaw

k.maraszek@uw.edu.pl

\title{
Review of: „Miłość i ekonomia w literackich biografiach kobiet” [eng. Love and economy in literary biographies of women] by Katarzyna Szmulewicz, Warsaw: Instytut Badań Literackich PAN, 2017. Pp. 206.
}

The book by Katarzyna Szmulewicz is not easy to qualify. On the one hand - as the author herself declares - it is an attempt to show through literary biographies of women "most ruthless social mechanisms crushing women`s potential" (p.11) and the emergence of the strategy of women's resistance and empowerment, who in different epochs (starting from Victorian era) struggled for the right to be visible. Therefore, the book may be recognized as a voice in the feminist discourse on the emancipating, liberating role of literature; and the particular biographies may be seen as the stories of women's experiences, leading to a recognition and consequently cancellation of the domination of men's view on the nature of social processes. Yet, on the other hand, the Author has an ambition to indicate an educational dimension of biographical stories which - as nothing else - are a tool for "constructing, reflecting and assessing the processes of individual learning and development" (Danuta Lalak), in this case of women in specific socio-cultural realities. These two dominating concepts are seen both in the structure of the book as well as the interpretations of life trajectories of the book characters, presented by the Author.

The book comprises 10 chapters presenting literary heroines from various epochs and of various material background, who attempt to cope with the title love and economy in the harsh world dominated by inequalities determined by gender and social position. So we learn about heroines from the Victorian novels by Jane Austin, Charlotte Brontë, Charles Dickens, Wilkie Collins and also by $19^{\text {th }}$ century French writers like Alexander Dumas and Émile Zola and Norwegian playwright Henrik Ibsen. In the subsequent components of the book the Author focuses on the fate of female characters from various social classes: servants (Kaśka Kariatyda by Gabriela Zapolska, Granica by Zofia Nałkowska) and upper class women, involved in affairs with men- servants. The last chapters present the reconstructions of the fate of women from the novels by Alice Munro, Marylin French ("non-working" ladies of 
burgher`s houses), Toni Morrison and Alice Walker (black Americans from US southern states) and Elfriede Jelinek and Marlene Streeruwitz (young, erotically entangled women from the proletariat). They are divided by a lot: their status, skin colour, type of work performed, declared or implemented erotism. They are united by one thing: the power that money has over them and the men that manage it and determine a social level playing field. Their common feature involves their attempts to satisfy their own needs interpreted as the expropriation and usurpation of what is naturally attributed to men (like feeling a sexual pleasure or unconstraint use of their property). Yet, the price they pay for experiencing and defining the world their way is high: "loss of bonds, respect and livelihoods" (p. 197).

The theoretical frameworks of the conducted analysis are determined by the theories from the socially - oriented literary criticism (Terry Eagleton, Roland Barthes), postcolonial afterthought (Edward Said) and feminist philosophical concepts (standpoint theory, analysis by Luce Irigaray, bell hooks, Christine Delphy, Monique Witting, Adrienne Rich). The publication also includes references to The Theory of the Leisure Class by Thorstein Veblen or The Feminine Mystique by Betty Friedan.

Putting together her book, based on the analysis of literary biographies of women, the Author sets herself an ambitious task of reading of "how female characters from various epochs interpret and transform their experiences and how it all affects their life" (p. 15). She also raises the question about the strategies, forms of resistance and survival adopted by women in the patriarchal world managed and organized by men. She also tries to discover "how they may help us with emancipatory understanding and shaping our own fate" (p. 12) and also assumes that literature, as a field of research analyses is particularly interesting, as it "combines biographical experiences of many individuals and presents them "from within", which is not done by a classic sociological analysis" (p. 15). The Author especially finds a close bond with the voice of the oppressed: female slaves, proletarians, servants who due to the frames determined by material relations are dominated not only by upper classes, but also by male "viewpoints" marginalizing the actions attributed to women: motherhood, house chores, care about others. Thus, the book presents "the reconstruction of what has been suppressed" (Jürgen Habermas) to be able to "resonate these days, participate in contemporary discussions" (p. 197). The theory of undisturbed communication of Habermas, referred to by the Author, indicates that the essence of communication means the process of approaching to internal, inter-subjective understanding of the partner, which may take place solely through a democratic exchange, where both parties voice their opinions. There is no place for jamming or suppressing opinions, there is discussion, negotiation and 
argumentation. The women's biographies contained in the book "stifled emancipatory voices from the past" (p.197) are then a pretext to continue discussions on emancipation, presented by the Author in her previous book: Emacypacja poprzez wychowanie, czyli edukacja do wolności, równości i szczęścia (Emancipation through upbringing, that is education towards liberty, equality and happiness) (Gdańskie Towarzystwo Psychologiczne, Gdańsk 2011).

The attempt to present in scientific frames literary biographies of women, undertaken by Katarzyna Szumlewicz, is bound to be well received both by literary researchers and critics as well as teachers. Yet, some crucial issues should be noted which must not be skipped by a careful reader of the book. Firstly, in this erudite and excellently written book we encounter supersaturation with the contents. A broad range of the analysis, not entirely clear criteria and seemingly accidental and personal selection of the literary works and female characters somehow obscure the style and the language of the Author and her research objectives. The reader may not be entirely satisfied with the fragmentary analysis of biographies in the context of the theories indicated by the Author and mentioned by her in the introduction. Nonetheless, this does not diminish the most crucial asset of the book that is its interdisciplinarity and usefulness for all those seeking educational character of biographical processes. 